\title{
Armed combative traditions of Latin America and the Caribbean: a hoplological overview
}

\author{
Michael J. RYAN* \\ The State University of New York - Onteona (United States) \\ Received: 24/17/2019; Accepted: 06/08/2020; Published: 24/08/2020.
}

\begin{abstract}
Over the last few decades, there has been a resurgent interest in New World martial art traditions. The bulk of the attention has focused on African and African diasporic traditions. Many well-researched books and articles have resulted from this focus. Yet, there is much less interest regarding other combative modalities brought to the shores of the New World. For centuries immigrant communities have brought with them sophisticated combative systems that persist to this day. As part of a broader hoplological project, this article seeks to identify and document the diverse armed combative systems still extant and practiced in South America and the Caribbean that have not transformed into solely institutionalized sports or recreational pastimes. With few exceptions these arts continue to be taught, practiced, and used in a variety of informal situations to ensure one's property or public reputation or as part of an economic strategy in the informal economy. At times paralleling and overlapping these more pragmatic goals, these arts also persist as a way of preserving older cultural moralities, ethics, and forms of masculinity.
\end{abstract}

Keywords: Martial arts; South America; Caribbean; Hoplology; armed combat; honor.

\section{Tradiciones de combate con armas en América Latina y el Caribe: una visión hoplológica \\ Resumen}

Durante las últimas décadas ha resurgido el interés por las tradiciones marciales del Nuevo Mundo. La mayor parte de esta atención se ha centrado en las tradiciones africanas y en las tradiciones africanas de la diáspora, publicándose numerosos libros y artículos bien fundamentados en la investigación. Sin embargo, ha existido un interés mucho menos respecto a otras modalidades combativas traídas a las costas del Nuevo Mundo. Durante siglos, las comunidades inmigrantes han llevado consigo sofisticados sistemas combativos que aún perviven en nuestros días Como parte de un proyecto hoplológico más amplio, este artículo busca identificar y documentar los diversos sistemas de combate armado aún existentes y practicados en América del Sur y el Caribe, que no se han transformado en meros pasatiempos deportivos o recreativos. Con pocas excepciones, estas artes continúan siendo enseñadas, practicadas y utilizadas en diversas situaciones informales para asegurar la propiedad o la reputación pública de los individuos, o como parte de una estrategia económica de la economía informal. En ocasiones, de forma paralela y superpuesta a estos objetivos más pragmáticos, estas artes también persisten como modos de preservar formas culturales de moralidad, ética y masculinidad más antiguas. Palabras clave: Artes marciales; Sudamérica; Caribe; Hoplología; combate armado; honor.

\section{Tradições de combate com armas na América Latina e no Caribe: uma visão hoplológica} \section{Resumo}

Nas últimas décadas, tem havido um interesse ressurgente nas tradições de artes marciais do Novo Mundo. A maior parte da atenção se concentrou nas tradições africanas, incluindo as de diáspora. Muitos livros e artigos bem pesquisados resultaram desse foco. No entanto, há muito menos interesse em relação a outras modalidades de combate trazidas para as costas do Novo Mundo. Durante séculos, as comunidades imigrantes trouxeram consigo sistemas combativos sofisticados que persistem até hoje. Como parte de um projeto hoplológico mais amplo, este artigo procura identificar e documentar os diversos sistemas de combate armado ainda existentes e praticados na América do Sul e no Caribe que não se transformaram apenas em esportes institucionalizados ou passatempos recreativos. Com poucas exceções, essas artes continuam a ser ensinadas, praticadas e usadas em uma variedade de situações informais para garantir a propriedade ou a reputação pública ou como parte de uma estratégica econômica informal. Às vezes, paralelamente e sobrepondo-se a esses objetivos mais pragmáticos, essas artes também persistem como uma maneira de preservar moralidades culturais mais antigas, ética e formas de masculinidade.

Palavras-chave: Artes marciais; América do Sul; Caribe; Hoplologia; combate armado; honra. 


\section{Introduction}

Over 30 years ago, the article "Black Martial Arts of the Caribbean" by the Yale Art Historian Robert Ferris Thompson (1987) opened many reader's eyes to the existence of the many Africaninfluenced combative traditions in the Americas. His all-too-brief descriptions of Afro-Caribbean combative traditions also opened many young scholars' imaginations to the possibility of other unknown arts in Latin America and the Caribbean. The ensuing years have seen the spread of Capoeira and Brazilian Jiu-Jitsu throughout the world. Yet there has been little academic or public interest in the many traditional non-institutionalized South American and Caribbean combative arts practiced today. The innumerable ways combative arts are still used throughout the world suggests they continue to serve an essential role in the everyday life of many people. Unfortunately, many of these arts do not meet the aesthetic or pragmatic needs of scholars, athletes, and those interested in "self-defense" and so remain overlooked and marginalized and, at times, outright dismissed as too extreme. As part of a larger hoplological project regarding the combative traditions of the New World, this article seeks to identify and map out the existence, variations, and extent of local systems of armed combat. Almost all these still remained outside the purview of government recognition. Many have resisted the trend towards domestication as purely combative sports, self-defense methods, or performative folkloric acts.

Among those communities who do not enjoy stable political-economic institutions or value self-help strategies of interpersonal violence, the knowledge of some form of fighting can be a necessity to walk the streets (Ryan, 2016). In other places, combative traditions are valued as a marker of identity by those resisting the domestication of the "warrior spirit" central to their ideas and practices of Masculinity (Boretz, 2011; Carton \& Morrell, 2012; Zorn, 2002). One concern driving this project is that in overlooking these arts, the understanding of how violence in everyday life is looked upon and managed by non-elite communities is subject to a skewed and partial understanding hindering the recovery of forgotten or marginalized histories (Wolf, 1982). Moreover, the practical orientation of these corporeal knowledges can correct a fixation on the discursive nature of power underlying many current martial arts studies. Attention can again turn to the role of physical force and the ways it practically, culturally, and effectively shapes our livedexperiences.

There has been an increasing number of works have looked at martial art traditions around the world (Desch-Obi, 2008; Farrer \& Whalen-Bridge, 2011; Green \& Svinth, 2003, 2010; Jones, 2004; Sánchez \& Spencer, 2013), hitherto except for a few exceptions many local traditions in the New World remain overlooked. Outside of entradas, civil wars, and raiding parties, the first mentions of civilian combative traditions in Latin America and the Caribbean come out of accounts of missionaries, explorers, or ethnologists. Written more as an interesting yet minor curiosity, scientists, adventurers, or missionaries often casually mention these traditions in passing (Eastwick, 2013; Landes, 1947; Wagley, 1977; Grub, 1913). Among the first to write of local combative traditions as a legitimate subject in their own right were local chroniclers, scholars, and practitioners in Martinique, (Michelon, 1987), Argentina (Osornio, 1995), and Brazil (Rego, 1968; Waldeloir, 1968). Or they contributed to theoretical concerns relevant to their disciplines (Chacón \& Mendoza, 2007; Lewis, 1992; Zorn, 2002). Others wrote about combative traditions they invested years of their lives in learning (Almeida, 1979; Capoeira, 2002; Coutinho, 1993; Forde, 2018; Pastinha, 1964; Sanoja, 1984).

\section{A "New Hoplology"}

Often when reading contemporary martial arts oriented studies, one noteworthy element is the way many of these works treats the actual art under examination in a perfunctory manner. After a quick overview of the art itself, the author spends the majority of the work engaged in contemporary discourse-centered theoretical debates. All too often, it seems scholars try to disguise their interest in what is in many departments is still seen as not quite a legitimate subject. One consequence of this approach is to reinforce the illegitimacy of combat arts as a valid source of study. Furthermore, it moves scholarship further away from the ways people learn to move and use their bodies accompanied by material technology in a wide range of combative modalities. 
As the discipline of anthropology was emerging as an institutionalized discipline in the middle of the 19th century, the equally new field of hoplology paralleled or often overlapped with ethnological and anthropological field studies of the Other. Previous publications have dealt with this topic in greater depth (Ryan, 2018). Briefly put, in the words of the founder of hoplology Capitan Sir R. F. Burton, Hoplology is the "The science of arms and weapons of offense and defense human and, bestial" (1884, p. 6). From this early attempt at defining the scope of the field, there has been a broad range of approaches and research methods as antiquarians, military observers, ethnologists, anthropologists, and lay scholars all contributed to the field over time (Pitt-Rivers, 1867; Mauss, 1934; Todd, 1938; Draeger, 1973; Skoss, 1997). Time and again they produced robust descriptions and valuable insights in the ways many peoples armed, trained, and fought in socially acceptable, efficient, and effective ways. The interest in Hoplology receded after the bloodbaths of WWI only to be revived again after the even greater horrors of WWII. A great deal of work came out of this revival from the 1960s to the 1980s but again, either failed to keep abreast of theoretical advances or remained of interest to only a small niche of scholars interested in medieval Japanese traditions. The Chinese government-funded another series of hoplological projects in the 1970s, but their findings were rarely translated and marred by strong ethno-nationalist or ideological considerations.

Building off older approaches, a "New Hoplology" considers armed combat a natural and regular part of the human condition. A Hoplological approach also recognizes that most every combative encounter is armed. Supporting this assertion is the fact that the overwhelming majority of pre-WWII civilian combative traditions treated unarmed combat as an auxiliary component of armed combat. Next, combat can be more productively seen as an embodied event where the physiological and neurological structures of those individuals taking part in the action shape and, in turn, are shaped by cultural norms of what is right, effective, and efficient and so changes over time and across space (Lende \& Downey, 2012; Ryan, 2016). Combat also occurs by individuals accompanied by some form of material technology. From covering the body with shoes, clothes or armor, to arming the individual with knuckledusters, spears, or assault rifles, material technology plays a crucial role not only in the way combat takes shape but in how one's subjectivity emerges through this relationship (Warnier, 2011). Although there is much more to Hoplology, these are the broad understandings of combat a hoplologist brings to the field.

The aim of this article seeks to identify and map out the range and distribution of those New World combative traditions extant today. With this knowledge, further research will examine how these arts are trained, thought about, and used. For an article with such a broad scope, the author relied on several methods of data collection. Nine field trips were made to South America and the Caribbean from 1992 to 2018, lasting from one to seven months. Almost every trip was predissertation or dissertation research projects. The 2018 expedition was done as part of a larger inter-disciplinary project under the auspices of The Immersion Labs Foundation (ILF). For other data, the author has relied on oral accounts and written sources cited in the text.

\section{Armed rural and urban combative traditions}

Many times, while conducting research in South America and the Caribbean, one may find oneself sitting on a bench underneath a tree listening to the older men talk about their youth. Often a researcher will hear the same refrain that goes something along the lines of "back in the day one needed to carry a weapon to walk the streets like a man." What this meant was that one did not have to be a master-at-arms or particularly care for fighting, but a man had to be prepared to show others he was armed and prepared to stand up to protect himself, his property, or his reputation. In these places, seemingly ordinary occupational tools or a stick often serve as the first weapon of choice. Not merely a handy tool, a weapon such as a stick, a machete or a knife would also serve as an icon of one's subjectivity. It could act as a gender, ethnic, or class marker, demanding all attendant privileges and entitlements that accompany a social position. The choice of a weapon or its handling could also act as a culturally established brake on unrestrained violence. Blunt percussive instruments such as sticks or rocks or flexible weapons such as whips, even knives, and machetes, depending on how their use, can be employed in a way to minimize the risk of 
catastrophic damage. Wielded or aimed in specific ways allowed men to exhibit their courage and burnish their honor while minimizing the possibility of death.

Overall, the evidence suggests the number of armed combat arts greatly outnumbered unarmed combative traditions in the New World. However, by the early to mid-20th century, a number of these traditions had been forced out of existence or withered away as a result of the latest wave of modernity to roll across the region. The range of causes might veer from the imposition of a modern state able to establish and maintain their legitimacy of the right of violence, a growing public intolerance for more extreme forms of masculinity, to the bourgeoning popularity of recreational pastimes from Western Europe or North America with an emphasis on fair-play transparency and sportsmanship.

\section{The Arts}

\subsection{Bajan Sticklicking}

Sticklicking in Barbados was not too long ago highly popular throughout the island and treated as a valued skill. Written accounts of the art only go back as far as the 1940s. The number of different styles remembered as being practiced at one time, such as Donelly, Maps, Square, Diamond, Sword, San Francis, Queensbury, and Johnson, suggest a once greater popularity. Of these, only the last two remain at present. Sticklicking, as a leisure activity up through the mid-1960s, took place around social events ranging from dancehalls, casinos, and house parties. Matches took place in a variety of formal and informal sites such as a boxing ring, a marked off area, or just within a circle of spectators. In the more formal spheres, fighters competed in three-minute rounds with one-minute rest periods. Judges enforced a rule system based on points given for successful hits or knockouts, and prize money offered to the winners. Neighborhood champions would also travel to other parishes to challenge other resident champions. Friends and family and fans would rent trucks or walk to these matches to support their local heroes. On a more informal level, weekends, especially Sundays, were times for informal house parties where Tuk bands played, people could by drinks and food from the woman of the house, and men could fight all night long in refereed bouts. Finally, even more, informal, and spontaneous fights broke out at parties and rum-shops. Rules governing sticklicking bouts prohibited the hitting of a person when his back was turned when he dropped his stick or when he was lying on the ground. Understandings such as these further reinforce the influence of ideas British ideas of sportsmanship affecting the art attesting to its adaptability to changing circumstances. Around the mid-1960s when Barbados won its independence, sports such as cricket began to gain in popularity, almost wiping out the existence of local art Sticklicking. Today, there are only three active teachers left on the island, which at times give demonstrations at schools and state holidays to promote the island's heritage (Forde, 2018).

Sticks were approximately 39" or longer hardwood stick held in one hand. Although one older informant relates how in his youth, some sticklickers held their stick with two hands on the end, similar to Trinidadian Boismen. In addition to fighting with sticks, some also learned how to fight with empty hands alone, and in conjunction with a stick that included punches, slaps, kicks, trips, hip, and shoulder throws. The broad array of tactics suggests a wide range of combative moves to deal with a variety of older combative modalities, or the rough and tumble nature of combat where one does anything needed to win.

The value of possessing sticklicking skills to increase one's financial or cultural capital is evident in a few instances. For example, up through the 1960s, police officers would pick-up locally renowned sticklickers to help arrest particularly noticeable troublemakers. Their reputation as ferocious fighters was carried with them as part of a long ongoing pattern of Barbadian emigration to escape the overpopulation and depressed living conditions back home. Many times, their skills with their sticks were often used by colonial governments security units or plantation owners to quell political violence or labor unrest. In fact, the local form of British Guyanese stickfighting of Setoo supposedly disappeared in favor of the proven efficacy of Barbadian Sticklicking (Forde, 2018). Such was the reputation of a Bajan stick-wielding man that it was said, "Stickman doh 'fraid no damom." In other words, with a stick in his hand, a Bajan man would strike fear in the devil himself. 


\subsection{Garrote Venezolano}

The definitive history of Garrote in Venezuela has yet to be written. Most research on Garrote has focused on its development in the Segovia highlands. Research the author conducted in 2005 and 2013 has shown there was or still is notable pockets of Garrote throughout many regions of the country with some local styles having possible links to Caribbean stick fighting arts. As Garrote is still practiced in a few far-flung regions of Venezuela, each with their unique history of emergence and development, the question arises was Garrote one art or many? The available evidence points to the idea Garrote emerged out of the migration from Spain and the Canary Islands. The term Garrote refers to a tapered and oiled hardwood walking-length stick, that was once an integral part of a man's public dress. The term Garrote also refers to the way the stick served as a civilian system of self-defense. By the early 20th century, Garrote had faded away along in the densely populated urban areas along the coast. However, trends moved much slower as one moved away from the coast. Until the late 1950s, in the Segovia Highlands of midwestern Venezuela, a man would not appear in public without his garrote, regardless of his level of skill. In even more rural areas, men defied the ban on carrying garrotes in public until the 1970s. Nowadays, men keep their garrotes behind their front door, strapped to their mopeds, or in the trunk of their cars when the need arises.

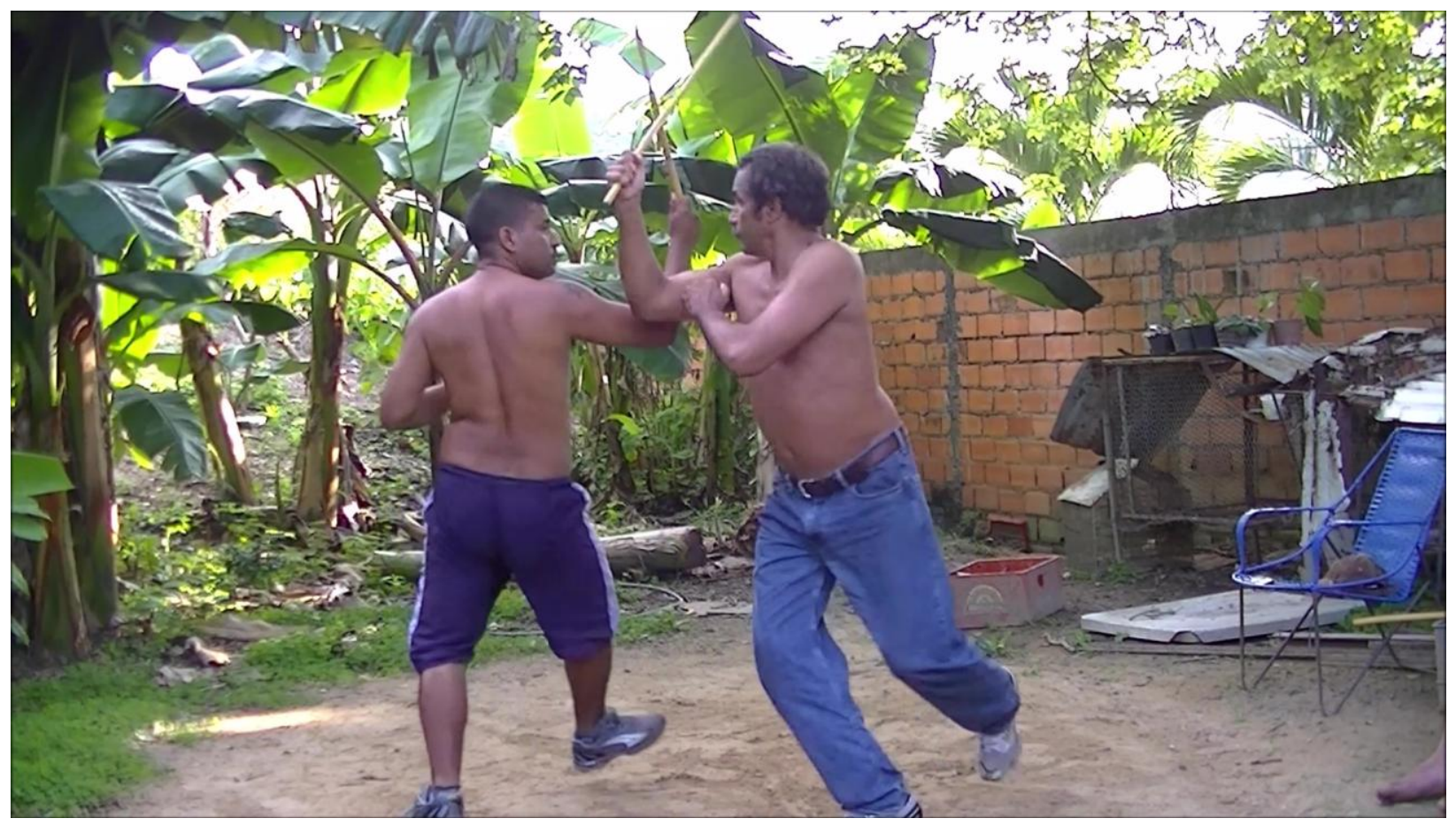

Picture 1. Playing La riña con palo style of garrote in La Piedad - Venezuela.

Garrote was always seen as an art of the pueblos, although from the mid-19th century, chroniclers took note of how some individuals studied Spanish military saber, local garrote styles, or Canarian stick arts. The way that these arts were individually recognized suggests that the writers knew enough about the history and culture of local combat and felt it was important to keep the military and civil combative repertoires separate. Furthermore, it indicates that local men sought to improve their skills in armed combat through an open-minded, practical examination of available combative repertoires. It was an often said that "garrote was never meant to kill just gain respect," suggesting the stick was used in intra-communal disputes to reduce the outbreak of unrestrained violence and the spread of blood feuds in a place where state control was weak, there was a concern to protect one's public reputation and, interpersonal violence was an accepted way to resolve conflict. If individuals sought to kill another person, they would turn to the blade and later increasingly firearms. Some styles of Garrote only trained with the stick or palo other styles trained with the palo, the machete, and the knife. Policeman up until the 1950s in the city of Barquisimeto were armed with machetes and learned to use different parts of the weapon to inflict pain, break bones without cutting, or slicing open bodies depending on the severity of the offense. 
This type of knowledge again points to the existence of a highly advanced method of civil combat developed by local security forces to maintain order. Garrote was also a rough brutal recreational past time where young men could while away the time between friends. Finally, Garrote was also valued as a method to teach young men physical toughness, mental resilience, and a set of quick reflexes and a sharp mind to set up and escape tricks, ambushes, or other traps that might be set by those claiming to be a friend.

Venezuela has been called "Latin America's least Catholic county" (Dineen, 2001). Nevertheless, there are numerous traditions of the local worship of saints. In the present-day state of Lara, there were only two cities, a couple of towns, and a dozen villages in the region that originally celebrated the feast of St. Anthony of Padua. Sometime in the early 20th century, Garrote became incorporated into this religious ritual. Not too long afterward, local scholars turning to popular cultural manifestation began to write about the beauty of these local festivities. Finally, in 1948, the newly elected civilian government of Venezuela co-opted this local festival seeking to unite the diverse people that made up this country but had no broader identity beyond that of a city or province. The new government changed the festival's name to the "Tamunangue" and used the ritual to highlight the idea that the rite, much like the nation of Venezuela, is a result of the blending of Indian, African, and European peoples and their cultures.

In addition to inventing a history and raising a local religious ritual to the status of a national icon to support the rule of the new government, the state had to make the stick fighting aspect of the ritual more in line with western ideas of decorum and gravity. Furthering this change meant cracking down on using the ritual as a place to settle personal or family feuds, or sometimes the sheer visceral joy of getting into a good fight. Instead of two men fighting with heavy wooden sticks, knives, or machetes in friendly and sometimes not so friendly matches, now men and women swing thin sticks at each other very fast and far enough away, to avoid any injuries. Nevertheless, in the working-class neighborhoods and rural hamlets of the region, real violence with sticks and blades still breaks out as on occasion, embarrassing the more "educated" and "refined" members of society. Continuing outside the Segovia Highlands where tourism plays a minor role in the economy garrote as a formidable system of combat is still taught as it was in the past and valued as a special cultural treasure of the rural peoples of Venezuela.

\subsection{Grima}

Grima, like Garrote, is best seen as an umbrella term for several predominantly AfroColombian armed combative systems done with a single stick or machete or stick and a machete in each hand. "Peinillas" or a shorter thinner machete, double peinillas, lance, knife, whip, and the straight razor are also taught in some styles today. Also, like Venezuela, there are multiple styles in existence. Of the 35 styles still practiced today, often, the art survives only in the bodies of older men or a family. Sombra Caucana, Palo Negro, Cubano, Español, Frances, Relancino, Venezolano, el Costeño, Sombra Japonés, are some of the most popular styles existing at present (Desch-Obi, 2009). However, all these styles are similar and share a common core of eight strikes and fundamental defenses (Desch-Obi, 2009). What is unique in the history of Grima was that due to economic conditions early in the 20th century, may people left the Cauca region where Grima originated for other areas of Venezuela, including many skilled in Grima. Looking to make a living, they began to teach professionally and spread the art around the country. The contribution of AfroColombians in general and their art of Grima has long remained in the shadows of Colombian history (Herrera, 2016). Both in the Wars of Independence in the early 19th century and the "War of a Thousand Days" in the early 20th century, the blade proved to be a principal offensive weapon. Recruited to serve in the border war with Peru, Afro- Colombian recruits soon found out that the single-shot rifles issued to them were no match for the modern repeating rifles the Peruvian soldiery possessed. Throwing their worthless rifles aside, the solders hailing from the Cauca region comfortable with close quarter combat took to using the machete or the peinillas as their primary assault weapon.

Throughout Latin America and the Caribbean face-to-face social interactions, a relationship of reciprocity and mutual obligations still shapes personal interactions. Where one's social reputation was highly valued, easy to damage, and called for almost daily maintenance to uphold.

Rev. Artes Marciales Asiát., 15(1), 34-49 2020 
Frequently, acts of violence were accepted ways to increase, protect, or regain one's social reputation or honor. Grouped under the name of "honor contests," fights would often break out at informal sites such as bars, parties' dances, or other sites where young men would gather during their leisure time and drink and show off in front of young women. At other times, honor contests could occur in more formal settings where two men would meet at a pre-arranged time where one's honor could be contested and affirmed.

Taking advantage of the ubiquity of the honor cultures in the New World, skilled Grimadores migrating out of the Cauca were able to provide a culturally valued and highly effective way of settling interpersonal contests. A strong tradition of the professionalization of sticklicking teachers is also present in Barbados and a lesser more scattered degree in Venezuela. What is interesting about these teachings in Colombia, Barbados, and parts of Venezuela is the formalization of a pedagogical regime versus a more intuitive type of training based on full-contact sparring. Although a very highly sophisticated form of training, it is extremely brutal and not for the weak of spirit. The widespread embrace of dueling with blades became so popular that in the late 19 th and early 20th century, schools developed specialized guards meant to draw an opponent to attack specific ways. This strategy, in turn, led to other schools that developed counter- guard tactics designed to overwhelm a guard and style of a competing school specifically. For example, if one man was skilled in the Grenadino style, another man might find a school specializing in the Venezolano Moderno style to overcome their strengths. Colombian Grima, too, was unique in the integral role women played in this art with many men freely acknowledging the high level of skill some women, a situation only rarely seen in the other traditions examined here (Desch-Obi, 2009).

\subsection{Tiré Machèt}

Interviews with practitioners of the Haitian machete claim their art took shape towards the end of the 19th century as a blending of African stick and sword with French infantry and cavalry sword traditions. As of today, there is an unknown number of semi-secretive family systems still in existence that, as in other places, makes it challenging to come to a clear understanding of the diversity of combative traditions. In his description of Haitian machete training, Desch-Obi describes his learning experience as taking place on a very intuitive level. A student would be taught an attack and then try to learn how to block and counter through watching others, or through a process of trial and error (Desch-Obi, 2009). As opposed to this type of approach, a style of machete taught by the Avril family relies on a more systematic pedagogy where the teacher first instills a robust defensive foundation to prepare the student to withstand a concerted attack (Haitian Fencing). From this point, students learn how to launch attacks, then block or avoid an attack and counter. Due to the lack of material available at the time, there is not much information available about the use of the machete in spontaneous duels, at parties or bars, or used by those in the informal economy such as selling drugs, committing robberies, burglaries, and assaults.

\subsection{Jamaican Sticklicking}

Jamaica was unique among the countries in the New World, along with Brazil, Colombia, and Suriname, as having a strong tradition of maroonage and the persistence of local combative traditions. In general, one should be wary of creating too strong a connection between maroonage and the persistence of Afro-descended combative traditions. Barbados provides an interesting exception to this scenario as having experienced only a slight tradition of maroonage, yet sticklicking persisted throughout the island until the 1960s. Be that as it may, the history of Jamaica as it pertains to civilian combative traditions began when the English captured Jamaica from the Spanish in 1655. From this point, sugarcane plantations in Jamaica rapidly increased between 1740 and 1790. With the expansion of this commodity came an importation of African prisoners- of war and an increase in maroonage. Here in the mountains among the maroon towns in Jamaica that we find the practice of stick fighting or Sticklicking persists.

The maroon communities continue a tradition of machete fighting and use the sticks as substitutes to ensure safety while training. The sticks used are similar in length to those used by Bajan sticklickers of a little over three feet. Other similarities with Bajan sticklicking include the lack of a musical accompaniment. There is a however a performative component done during the 
celebrations of "Jankanu" in December, where the sticklicking occurs in a more visually exciting way. Both Jamaican and Barbadian styles prefer a one-handed grip, which differs from the twohanded grips favored in most Afro-descended stick arts. Nonetheless, one informant claimed there is a Jamaican tradition of fighting with sticks using a two-handed grip. There are several notable differences between the two traditions, though. Jamaican Sticklicking emerged from the marron communities of a free African people in the mountains of Jamaica. In contrast, Bajan Sticklicking took shape among the sugar cane plantations, where due to environmental conditions, maroonage never played a significant role in Barbadian history. On a more technical level, the Jamaican preparation of the stick relies on West African Kromanti spirituality, also known as "Kromanti Obeah," while in Barbados, there was a mention of this by one informant, but in large part, there was not any "mounting of the sticks." The pedagogy was different, too, in that Bajan Sticklicking is taught through a carefully gradated level of sets of attacks and defenses known as "cuts" progressing from the simple to the complex. In Jamaica, by contrast, the training is more intuitive and taught through the means of a "war dance." Finally, the Bajan stick was the principal fighting weapon while in Jamaica, the sticks substituted for a machete (Forde, 2018).

\subsection{Kalinda Gilpin and Rope-Jab}

The development of Kalinda, The Rope-Jab, and Gilpin, much like most all arts in the Caribbean and a number in South America, relates to the expansion of sugar cane as one the principal export crops of the New World. England took possession of Trinidad in 1797, which by then African slaves were double the population of European inhabitants. After the abolition of slavery, the continual need for a reliable, docile, and a cheap labor force led planters to bring in indentured servants from India beginning in 1845. By the time WWI was going strong, and further emigration ended, an estimated 145,000 people had immigrated to the islands from India.

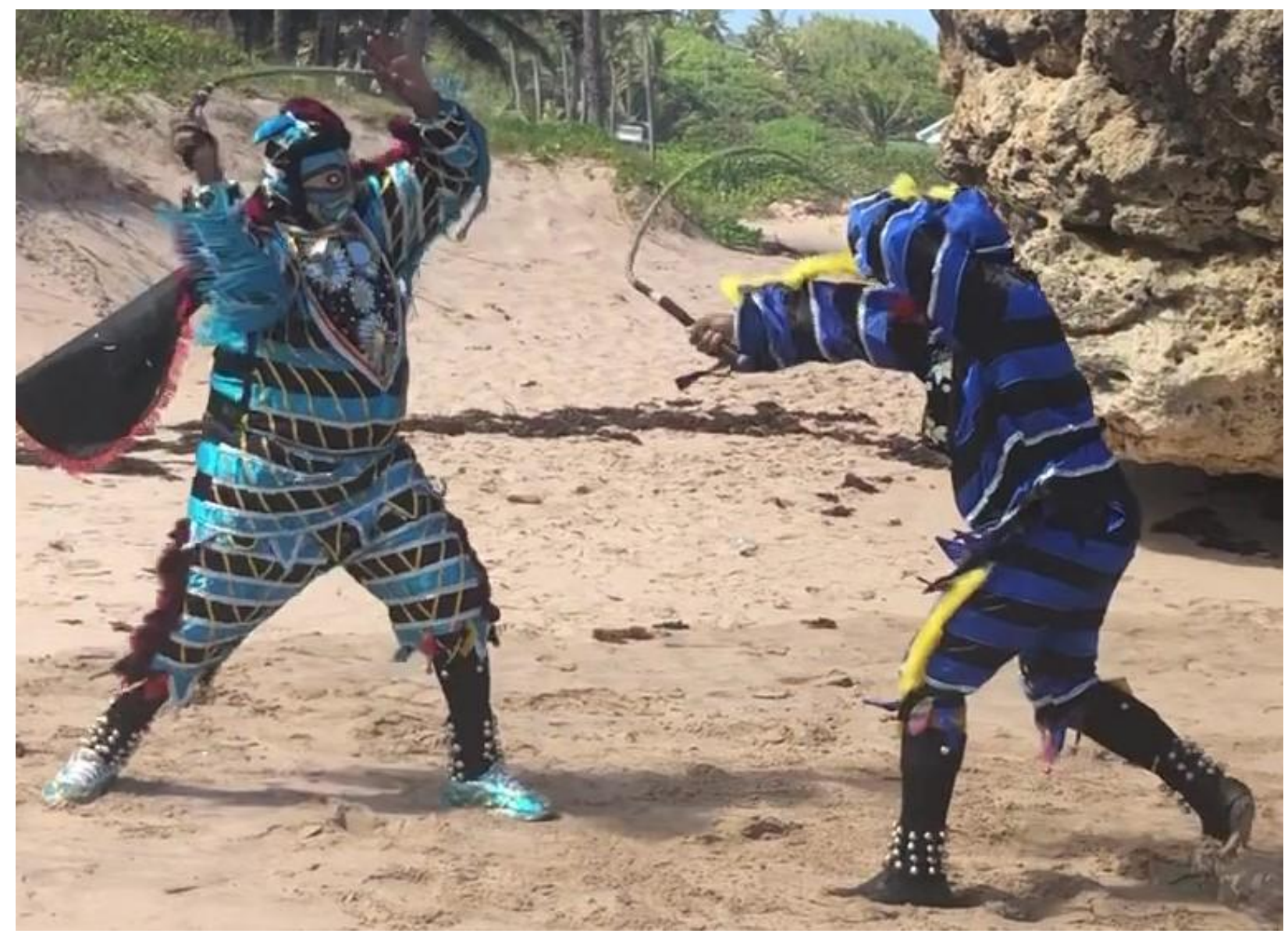

Picture 2. Rope Jab Warriors engage in ritual combat.

Kalinda and the Rope-Jab today are intimately intertwined with Carnival. Carnival was first celebrated in Trinidad in the late 18th century. Upon the abolition of slavery in 1838, free Africans 
began to celebrate their own Carnival processions in public places known as Canboulay, where once oppressed communities could celebrate their freedom from oppression and their collective power. Neighborhoods would construct floats, and costumed revelers would march up and down the street (Hill, 1972). Upon meeting other neighborhood Canboulay groups, boasts and taunts directed towards each other would often lead to challenges and ritual duels with heavy hardwood sticks leading to a never-enforced ban on Canboulay in 1868. In addition to intimidating and repelling elites through their unique celebrations, "Boismen" or Stickmen would take the opportunity to harass, intimidate and assault local Indian merchants and laborers. In turn, this led to merchants hiring men skilled in the Indian stick art of Lathi to protect their community. During one notable riot in 1880, the local police chief of Port of Spain deputized a group of these South Asian fighters to help to quell the violence. By 1904, the Trinidadian state was able to enforce a ban on the carrying of sticks longer than three feet in length, hastening the decline of the art. A set of further restrictions on Kalinda players and African drummers in 1944 coincided with the events of WWII. The increased presence in allied ships and personnel in the area, in turn, contributed to the development of steel-pan music and local street fighters putting down their big two-handed sticks in favor of switchblades and other small concealable weapons to continue their contests and aid in their informal economic activities (Cowley, 1996). As we saw in Venezuela with Garrote, government recognition of Kalinda was part of a drive to create a sense of national identity among the diverse peoples on the islands. The 1940s saw a shift promoting once stigmatized rural African and South Asian cultures while marginalizing others such as Chinese. Finally, in the 1990s, Kalinda was again treated as an integral feature of Carnival.

At present, Kalinda is a formal stickfighting dueling art done with a hardwood stick approximately 48" stick. Kalinda is a refereed formal sport with one or more judges. In a very simplistic description of a Kalinda match, a group of drummers stationed alongside the gayelle or ring begins a rhythm, and the Chantwelle begins singing a chorus whose response is often picked up by members of a fighter's entourage and spectators. Two men enter the gayelle where they dance around the open space and each other, evoking their African ancestors. Each contestant then performs a solo series of dance steps to feel the spirits, to loosen up the body, and let the spectators know they are protected by the ancestors and invincible. The combat begins with striking below the waist, the only principle prohibition. The main target is the head where the Boismen seeks to cut the other man's scalp so that he bleeds. Disabling a man with body shots or leaving the decision to the judges is also a way to win. If a man's head is bleeding or "bus open," he is led to the "blood hole" in the center of the ring where he offers his blood to the ancestors, and the next match then begins.

The role of Gilpin as a double machete art claims the same social roots as Kalinda but withheld from public view until 2018. The movements themselves are taken from Kalinda's body movements as well. Gilpin was revealed to members of the Immersion Labs Foundation (ILF) hoplology expedition of the 2018 team because the instructors who were part of the team were afraid the art was going to disappear. The ILF is a Hoplological research group-oriented to exploring the commonalities and differences in armed combat as well as archiving disappearing combative art forms. Since 2018, The Immersion Labs Foundation has conducted three research expeditions to Barbados, Portugal, and the Philippines, completed one contra- expeditions and held three intensive workshops where exponents of local combative arts can demonstrate, teach and record their art, their life histories, and their reflections on their arts.

\subsection{Rope-Jab}

The profound influence on South Asian Indians in Trinidad and Tobago is especially visible in the Carnival "Mas" or costumes of the Jab-Men. The Jab characters are a later addition to the series of accepted costumed characters paraded during Carnival. They dressed in brightly multicolored satin costumes hung with bells and decorated with mirrors and rhinestones. On the head, a head hood with stuffed clothed horns protrudes, and other sacred symbols complete the mas. The Jab-Men lead the floats. Upon meeting another float protected by other Jab-Men, Duels commenced with long cactus fibered whips that can tear the cloth of a Jab-Man while leaving his skin intact, shred his skin to ribbons while leaving the costume whole, or cut the seams of the other Jab-Man's costume leaving him naked in the street. The predominant target, though, was the eyes 
resulting in numerous blind or half-blind Jab- Men and a decrease in the number of young apprentices. The shorter whip made of steel cables, in turn, can break bones and rupture internal organs. What is interesting about the Jab-Men are their strong links with the Indian herding cultures and the worship of the goddess Kali, Mariamman along with African Orixas. These men have highly specialized knowledge of local medicinal plants and hold themselves to a high degree of comportment all year long. One month before Carnival, they immerse themselves into an even more rigorous regime of fasting, mediations, visualizations, herbal baths, and prayer to prepare themselves for the upcoming whipping duels (oral communication with R. Alfred Nov 21, 2018).

\subsection{Machete}

The neighboring Dominican Republic likewise has a strong machete fighting tradition. The fragmentary evidence available suggests that machete fighting is shared among a small minority of people and employed as a culturally approved masculine way of solving disagreements. There are several pre-fight rituals to a machete duel, such as yelling threats to the opponent and scraping one's machete blade against the street preceding the actual confrontation. Fighters sometimes wrap one hand in a shirt in the lead or rear hand. At times, a fighter might his free hand behind his back, as done in Haitian machete, presenting a profile to his opponent minimizing exposure. Multiple assailants can launch an assault on a person or friends of the men, and fighters can throw found objects in the street at friends/relatives of the opponent to try to distract him (DiMarzio, 2012).

\subsection{Jogo do Pau}

Chroniclers have noted numerous accounts of armed combative arts among the urban centers of the Brazilian littoral over the centuries. Although the focus on unarmed combat combined with the present-day unfamiliarity or fear of weapons has marginalized the armed aspect of early Afro-Brazilian combative exponents. The evidence for this assertion can be found in the earliest mentions of Capoeira in the late 1700s and early 1800s in Rio de Janeiro where those ethnically marked men arrested for the crime of capoeira often possessed a stick and or a knife on them. The use of a knife as an occupational tool in many trades at the time could serve to explain to their possession of a prohibited weapon. What is difficult to explain away is the carrying of a stick. At the time throughout Western Europe, urban men carried walking sticks with them serving both as a gendered status icon and the weapon of choice of a civilized man. By the early $19^{\text {th }}$ century, it was no longer seen as necessary, nor was it legal to carry a rapier, a two and a half sword or halberd in public as it was two to three hundred years ago. Arming oneself with a weapon though was still a matter of common sense at the time. Throughout Europe and the New World, the presence of security forces was few and far between, and they were more concerned with preserving those governing the country than protecting the popular classes. The need to arm oneself with a stout stick to ward off thieves or robbers, packs of loose dogs, or beggars was considered quite normal. At the same time, the carrying of a stick could also be a sign of claiming a gentleman's status usually reserved for Europeans. With this in mind, the arrests of African, or Afro-Brazilian men carrying sticks for the crime of Capoeira hints at a broader definition of capoeira as more than a male recreational kicking game and point to ethnically marked men claiming the status of "civilized" men. The potentiality of thin walking sticks to serve as weapons is hinted in the description of a legendary figure from the past. One of the last of the politically allied Capoeira street fighters nicknamed "Manduca de Praia," was known for "only carrying as a weapon a fine walking stick of wood from India" (Assunção, 2014, p. 92). There are also several accounts of stick-wielding Afro-Brazilians fighting rural Portuguese immigrants armed with a hardwood stick about five feet in length swung with ferocity and power. Altogether, the evidence suggests there must have been a rich and varied set of armed combative techniques used by the popular classes along the littoral of Brazil that must have drawn on older African and European traditions. Most of these died out sometime in the mid-20th century, but at least one method still exists.

Among the former quilombo settlements of the Paraíba Valley in the state of Rio de Janeiro, a stick fighting system is still remembered and is enjoying a renewed interest (Assunção, 2014). Similar to other areas in the New World, sticks were carried as a part of everyday male dress, and fights broke out during leisure periods. Sticks were approximately a little over three feet long. Although there was a wide range of attacks, there were three favored attacks the "Thrust," the 
"Jawbreaker," and the "Snake-Killer" (Assunção, 2014, p. 123). At least two versions of the style of play existed. A friendly version kept the blows high, and a friendly verbal exchange went back and forth. A more antagonistic game would add leg kicks and sweeps meant to take the man to the ground. Practiced today as one-on-one dueling art, up until the 1960s, men fought with sticks in melee types of brawls pitting neighborhoods or families against each other.

\subsection{Esgrima Criolla}

Esgrima Criolla is a modern term to conveniently talk about the wide range of combative arts practiced by those of the Southern Cone of Argentina, Chile, Paraguay, Uruguay, and Southern Brazil. Like the rest of the continent, the Iberian valorization of the blade meant the use of a knife was and is often the main weapon of choice to solve interpersonal disagreements and display one's manhood. One problem with exploring the wealth of armed traditions in this area is a scarcity of published material relating to contemporary exponents. Talking to people who have lived in rural areas or whose family has lived in rural areas provides some information about the persistence of these traditions. Social -media sites also post grainy videos of prisoners fighting with stabbing spears, knives, and blankets or in an espada y daga style establishing the continued persistence of older ways of fighting are still valued. What we do have are accounts from the late to early $20^{\text {th }}$ century that gives us some strong descriptions of the weapons, used, and how fights took shape in the rural and urban areas of the region, creating a base to continue further research.

\subsection{El Facón}

The "Facón" is an iconic symbol of Argentine masculinity. The sight of a Facón evokes the same imagery of nation, history, resistance, and masculinity as the machete does in Colombia, The Dominican Republic, Haiti, or Jamaica. Moreover, the same parallels can be drawn with the iconic status the stick plays in the imagination of those from Venezuela, Barbados, and Trinidad. Among the gauchos, there were five principal types of knives, of which the Facón is the most recognizable. The Facón has a blade of approximately eight inches and a " $U$ " shaped guard. In the past, rural laborers wore wide leather belts decorated with silver coins that served more as a type of defensive armor and a bank while the knife was tucked into the back of the belt (Osornio, 1995).

Although the knife acted as the principal weapon, other occupational tools or weapons were also used such as the poncho, bandana, "boladeiro," or a throwing weapon the "chuzo" or the lance, the "rebenque" or the whip and even the "Chancleta" or leather sandal, when no other weapon was available (Esgrima Criolla, 2020). The poncho was also used as an everyday piece of wear as well as used in knife duels. Much like their knives, the Gaucho prized their ponchos just as highly, valuing them more than his horse. It was said the poncho served as a memorial to previous knife duels and never repaired after being damaged in a duel (Gauchos Knife, 1925). When fighting, the poncho is grasped by the left hand and given two quick flips around the forearm to act as a shield. The rest of the poncho hangs down where it can cover the position of a man's knife. Alternatively, it can be used offensively in several types of whipping or snapping types of strikes to blind, entangle, or otherwise interfere with the free movement of the opponent. Even the fringes decorating the sides of a poncho can snap at the opponent's eyes. A quick search of You-Tube videos of knife fights in prisons in this part of the world will show that men often use their blankets as their great grandfathers once used the poncho.

One man tells of his father, who was from the rural areas of Argentina, would use low kicks to injure, sweep or stop any forward movement by the opponent. Kicks were also used in conjunction with the hands which struck in open hand palm strikes, finger jabs, and closed fists (Esgrima Criolla, 2020).

One journalist, who witnessed several duels in the early $20^{\text {th }}$ century, described how duelists preferred downward thrusts because it was more difficult for men to attack the chest due to the presence of the ribcage. Attacks to the unprotected soft belly, however, had a higher chance of causing grievous wounds. For this reason, a downward thrust and ripping and upward motion in withdrawing the blade was the most sought-after type of strike (Arthur Mills, 1925). For defense, the knife parried, or the poncho blocked or parried. Duelists sought either to disembowel with quick "upward rips or if the intent of the attack is less lethal, he may merely seek to 'lame' the 
opponent through a slash on the face in order to permanently mark them as memorials to the skill of the victor" (Gauchos Knife, 1925).

In the same newspaper article, Arthur Mills describes a fight between a foreman who hailed from the mountainous regions of the North and a ranch hand. "Monteneros" from the mountains and high deserts of Argentina still possess a reputation for quick knife work. They did not fight with ponchos wrapped around their left arm but with double knives in a type of espada y daga style. They were also known for their use of the "caronero". A Caronero was more like a sword. It had a 31-inch blade sharpened on one side and traditionally was used to slaughter cattle.

With the demise of the open plains and the "fencing of the commons," by the late 19th century, the era of the gaucho had come to an end. Many men moved to the industrial slum's neighborhoods popping up around the port towns of the Rio Platte, where they could earn a living and carry on their recreational activities in a similar manner. The change of residences did not mean the end of a knife culture though just a receding of it to the margins of rural society. In the newly expanding urban areas, another unique style of knife fighting culture emerged through the use of a smaller knife known as a fiyingo.

\subsection{El Fiyingo}

A "fiyingo" has a smaller fixed handle single edge blade with a seven to ten-inch overall length. The smaller size reflected the need to hide the blade due to strict laws against the carrying of weapons in public. Another factor was the tighter, more closely fit clothing of urbanites that could not accommodate longer knives. Fiyingos were kept in the armhole of a jacket vest or under the lapel of the jacket for quick and easy retrieval in case of need. Dueling with knives were part of everyday masculine socializing practices where a man could demonstrate his courage, agility, and willingness to risk it all on seemingly minor matters. The value of the blade in Argentina at the time was deeply entwined with one's manhood that the father of the world-famous author José Lois Borges gave his son a knife. Complaining to his father how other children were bullying him, his father advised him to show some courage and begin stabbing them; then, he would be left in peace. Less one thinks that the father of this famous author had poor parenting skills; one must keep in mind during the same period varied source suggests this was a regular initiatory act in the transitioning to manhood. During this same period future, U.S. close-quarter combat instructor J. Biddle recounts as a youth growing up in Spain and the Canary Islands how fathers would give their young sons knives. Moreover, that "little Spanish boys [were] stabbing each other all the time" (Grover, 1942).

Far from random assaults on each other, these armed encounters among children as Borges remembered served as the first steps in a type of training in Argentina known as a "visteo." At these sites, young men trained their knife skills with varying degrees of safety from using sticks of wood with wood ash coated on the tip to show a hit, to dueling with sheathed knives. Visteos was one of the primary forms of male recreation until the late 19th century, along with drinking and visiting brothels until the British introduced "fútbol" into Argentina (Esgrima Criolla, 2020).

As in took place in Argentina, a common way to initiate a duel was for one man to compliment the other. From this point, the man would continue to heap compliments on the other man until he and the onlookers saw that really, he was mocking him. Once outside, surrounded by a referee and a group of peers, they could fight until "first blood" or until a serious injury. Even with a referee, friends could jump in and turn the duel into a melee, and even men having second thoughts could be physically pushed or jeered at by the crowd eager to see a good fight.

\subsection{Esgrima de Bastón}

Finally, a minor style of stick fighting in Argentina emerging in Buenos Aires in the early 20th century. Of the many styles of combat that immigrants brought with them to the capital, only the walking stick popularized by Arturo Bonafont continues.

By the beginning of the 20th century, Argentina was well on it's way to turning itself into a modern nation-state type. As part of this push to become a modern nation, a gentrification process took place along the port areas and downtown, where new infrastructural improvements were 
under construction. During this time, elite young men would regularly visit the lower class-vice zones mixing with other young less-privileged men and women drinking and dancing the Tango. At times, these encounters ended with challenges of a duel with knives. Even if they begged off claiming they were not armed, an obliging onlooker could obligingly offer his own knife to a man who "forgot" to bring his. Needless to say, this rarely turned out well for the rich kids. To protect themselves, many young men known as "dandies" joined fencing academies where they learned the sword, stick, and savate, and increasingly armed themselves with revolvers to neutralize the advantage of the underclass opponents. During this time of low-intensity class-warfare, a group of three men began a self-defense club in Buenos Aires "GEBA" (Club Gimnasia y Esgrima de Buenos Aires / Buenos Aires Gymnastics and Fencing Club). Here Arturo Bonafont started to teach a unique system of self-defense using the walking stick. Armed with a 37" hardwood stick, Bonafont preferred to use what he calls "two-handed grips" on both ends of the stick to deliver powerful thrusts and strikes when close. From further away, Bonafont advised readers to hold the stick in an "inverted grip" with the butt end protruding four to six inches in front of you and the remainder of the stick behind you. With this grip, Bonafont taught various attacks and counterattacking whipping blows with the long end of the stick by twisting the wrist and the elbow and striking the miscreant. As of present, two teachers still teach this method of stick fighting (Bonafont, 2018).

\section{Conclusion}

The history of the New World has been written about from many standpoints over the years. It was not until recently that attention has turned to the combative traditions immigrating communities brought with them, adapted from others, or changed to meet their current needs. Even with an increasing number of journals and conferences dedicated to combative arts, the preponderance of scholarly attention continues to focus on unarmed sports-oriented or other unarmed traditions. There are several good reasons for this. One possible explanation is that most martial scholars have trained in today and feel comfortable with unarmed fighting traditions. Related to this is the fact that fighting is dangerous, and once weapons of any kind come into play, the risk of serious injury escalates exponentially. And with good reason, many people shrink from this risk. Another alternative is that scholars are still influenced by the ideologies, moralities, and policies that marginalize and stigmatize violence without really trying to understand its role in human societies. Be that as it may, it is a fact that armed fights have always been the major focus of training both in the past and at present in many popular communities. Concerned only with making it to the next payday, many people around the world concern themselves with dealing with situations they will most likely face, and all too often, this involves armed confrontations and, for this reason, armed combat deserves to be examined. To be fair, the range and popularity of unarmed combative traditions are also deserving of study, just not at the exclusion of more common, perilous, or aesthetically less-pleasing modalities of combat. Recognizing the ubiquity of armed combat, a New Hoplology seeks to identify and document armed combative methods by those who have had in the past or still today rely on their skills with a weapon. With this type of renewed focus, a more complete understanding of non-elite communities, their views towards violence, methods of transmitting practically oriented knowledge, and the way they make their way through the world is opened up to a wider degree. Furthermore, we can deepen our understanding of the unique and everchanging ways that humans have come to arm themselves and meet each other with the intent of dominating or eliminating the other.

Several issues with this research paper deserve mention. One is the danger of creating too strong a divide between a sportive and performative and non -sportive combative arts. By the midmid-20 ${ }^{\text {th }}$ century, Barbados and Trinidad had developed a sport-oriented form of stick fighting. Similar to this trend, Venezuela, Trinidad, and Jamaica also provide instances of stick fighting being closely associated with local religious observations and concomitant domestication of the art occurring after WWII. In each case, while the performative version has received more attention, a more fighting oriented version of the art persisted with exponents regularly participating in both modalities. The case is that these combative modes are not mutually exclusive categories but exist more along the lines of the intention of each modality is radically different, shaping the types of weapons used and informing the mind-set of individuals enter a combative fray. 
There were several arts that the author has only heard accounts of or seen a few moves. In Mexico, there are at least two secret societies of knife fighters. One group follows the path of "good," and the other follows the "left-handed" path invoking the protection of "dark spirits." The Nordestinos' of Brazil living in the slums of São Paulo in the 1950s had a fearsome reputation with the knife, but little else is known. The father of renowned fencing master Ramon Martinez was a police officer in San Juan Puerto Rico and had learned 12 knife attacks. Of these, he taught six of them to his son (oral communication with R. Martinez, 2007). Another informant from Curaçao claimed stickfighting disappeared from the island by the $1960 \mathrm{~s}$.

The many and varied ways humans have come up, classified and organized ways to manipulate their bodies in conjunction with material technology to engage in modes of interpersonal combat ranging from the performative to the battlefield has always proved a fascinating topic of study. Out of such an interest arose the project of hoplology. The role of armed combat how it is trained, manifested, and expressed; who participates, who watches, how victory is adjudged are the some of the basic questions that can give shape and add another layer of understanding of the role that the human body, culture, and material technology mutually shape and impact each other in the formation of subjectivities and a communal habitus. Not only that, but a focus on armed combat can also uncover a fuller picture of non-elite communities and the way they have resisted the destruction of older ways of living, acting in, and imagining the world. These, too, as the historian Scott identified as "Weapons of the Weak" (Scott, 1987) and have yet to be given the seriousness and respect they deserve.

\section{References}

Almeida, U. (1981). Capoeira: A Brazilian Art Form. Palo Alto: Sun Wave.

Assunção, M.R. (2014). Sticks and Stanzas: Poetic and Physical Challenges in the Afro-Brazilian Culture of the Paraiba Valley, Rio de Janeiro. History Workshop Journal, 77(3), 103-146. doi: $10.1093 / \mathrm{hwj} / \mathrm{dbt} 007$

Assunção, M.R. (2005). Capoeira: The History of an Afro-Brazilian Art. New York: Routledge.

Boretz, A. (2011). Gods, Ghosts, and Gangsters: Ritual Violence, Martial Arts and Masculinity on the Margins of Chinese Society. Honolulu: University of Hawai'i Press.

Burton, R.F. (1987) [1884]. The Book of the Sword. New York: Dover Publications.

Capoeira, N. (2002). Capoeira: Roots of the Dance-Fight-Game. Berkeley: North Atlantic Books.

Carton, B., \& Morrell, R. (2012). Zulu Masculinities, Warrior Culture and Stick Fighting: Reassessing Male Violence and Virtue in South Africa. Journal of Southern African Studies, 38(1), 31-53. doi: $10.1080 / 03057070.2011 .640073$

Chacón, R.J., \& Mendoza, R.G. (Eds.) (2007). Latin American Indigenous Warfare and Ritual Violence. Tucson: The University of Arizona Press.

Couthino, D. (1993). O ABC de Angola: Os Manuscritos do Mestre Noronha. Brasilia: Centro de Documentação e Informação Sobre Capoeira-CIDOC/AF.

Cowley, J. (1996). Carnival, Canboulay and Calypso: Traditions in the Making. Cambridge: Cambridge University Press.

Desch-Obi, T. J. (2008). Fighting for Honor: The History of African Martial Art Traditions in the Atlantic World. Colombia: The University of South Carolina Press.

Desch-Obi, T. J. (2009). Peinillas and Popular Participation: Machete fighting in Haiti, Cuba, and Colombia. Memorias. Revista Digital de Historia y Arqueología desde el Caribe, 11. Retrieved from http://rcientificas.uninorte.edu.co/index.php/memorias/article/viewArticle/517

DiMarzio, D. (2012). From Machete Fights to Paradise: The Machete Fights of the Dominican Republic. Morrisville (NC): Lulu.com.

Dineen, M. (2001). People and Cultures of Venezuela. Greenwood Press. CT.

Draeger, D. F. (1973). Classical Bujutsu: The Martial Arts and Ways of Japan. New York: Weatherhill.

Esgrima Criolla. (2020). Esgrima criolla. Retrieved from www.esgrimacriolla.blogspot.com.ar

Eastwick, E. (2013) [1868]. Venezuela or Sketches of Life in a South American Republic; With the History of the Loan of 1864. London: Forgotten Books.

Farrer, D., \& Whalen-Bridge, J. (Eds.). (2011). Martial Arts as Embodied Knowledge: Asian Traditions in A Transnational World. Albany: SUNY Press. 
Forde, P. (2018). Blocking Both Head and Foot: An examination of Bajan Sticklicking. (Doctoral Dissertation). The University of the West Indies, Cave Hill Campus, Barbados.

Green T. A., \& Svinth. J. (Eds.). (2010). Martial Arts of the World: An Encyclopedia of History and Innovation. Santa Barbara, CA: ABC-CLIO.

Green T. A., \& Svinth. J. (Eds.) (2003). Martial Arts in The Modern World. Santa Barbara, CA: Praeger.

Grover, J. (1942). Great Granddaddy Biddle-A tough guy, and that something you don't have to tell to the Marines. Retrieved June 30, 2014, from https://bowieknifefightsfighters.blogspot.com/2010/11/bowie-knife-fighter-anthony-jdrexel.html

Grubb, W. B. (1913). An Unknown People in an Unknown Land: an account of life and customs of the Lengua Indians of the Paraguayan Chaco with adventures and experiences during twenty years pioneering and exploration amongst them. London: Charles Murray \& Co.

Herrera, S. C. (2016). A History of Violence and Exclusion: Afro-Colombians from slavery to displacement. (Master's thesis). Georgetown University. Washington D.C., U.S.A.

Hill, E. (1972). The Trinidad Carnival: Mandate of a National Identity. Austin: The University of Texas Press.

Jones. D. (Ed.). (2002). Combat, Ritual and Performance: Anthropology of the Martial Arts. Santa Barabra, CA: Praeger.

Landis, R. (1994). [1947]. City of Women. Albuquerque: University of New Mexico Press.

Lende, D.H., \& Downey, G. (2012). The Encultured Brain: An Introduction to Neuroanthropology. Cambridge: MIT Press.

Lewis, J.L. (1992). Ring of Liberation: Deceptive Discourse in Brazilian Capoeira. Chicago: The University of Chicago Press.

Mauss, M. (1979). [1934]. Sociology and Psychology: Essays. B. Brewster, transl. London: Routledge and Kegan Paul.

Michalon, J. (1987). Le Ladja: Orgine et Pratiqués. Paris: Editions Caribéennes.

Osornio, M. (1995). Esgrima Criolla: (cuchillo, rebenque, poncho y chuza). Ediciones Nuevo Siglo: Buenos Aires.

Pasthina, V. F. (1964). Capoeira Angola. Salvador, Brazil: Fundação Cultural do Estado Bahia.

Pitt-Rivers, A.H.L. (1867). Primitive Warfare. Parts I. Journal of the Royal United Services Institution, $11,612-643$.

Rego, W. (1968). Capoeira Angola. Salvador BA: Editora Itapuã

Ryan, M. J. (2016). Venezuelan Stick Fighting; The Civilizing Process in Martial Arts. Latham, MD: Lexington Books.

Ryan, M. J. (2019, Spring). Hoplology: The Quest to Discover and Understand Martial Arts. Masters Magazine, 30-39.

Sánchez, R., \& Spencer, D. (Eds.) (2013). Fighting Scholars: Habitus and Ethnographies of Martial Arts and Combat Sports. London: Anthem.

Sanoja, E. (1984). Juego de Garrote Larense: El Métodos Venezolano Defensa Personal. Caracas: Miguel Ángel García e Hijo.

Scott, J.C. (1987). Weapons of the Weak: Everyday Forms of Peasant Resistance. Yale University Press.

Skoss, D. (Ed.) (1995). Koryo Bujutsu: Classical Warrior Traditions of Japan. Berkeley Heights, NJ: Koryu Books.

Thompson, R. F. (1987). Black Martial Arts of the Caribbean. Review of Latin Literature and Arts, 20(37), 44-47. doi: $10.1080 / 08905768708594231$

Todd, F. P. (1938). The Knife and Club in Trench Warfare 1914-1918. The Journal of American Military History Foundation, 2(3), 139-153. doi: 10.2307/3038757

Wacquant L. (2004). Body and Soul: Notebooks Of An Apprentice Boxer. New York: Oxford University Press.

Wagley, C. (1977). Welcome of Tears: The Tapirape Indians of Central Brazil. New York: Oxford University Press.

Waldeloir, R. (1968). Capoeira Angola. Salvador BA: Editora Itapuã.

Warnier, J.-P. (2011). Bodily/Material Culture and the Fighter's Subjectivity. Journal of Material Culture, 16(4), 359-375. doi: 10.1177\%2F1359183511424840

Wolf, E. (1982). Europe and the People Without History. Berkeley: University of California Press. 
Zorn, E. (2002). Dangerous Encounters: Ritual Battles in Andean Bolivia. In D. Jones (Ed.), Combat Ritual and Performance: Anthropology of the Martial Arts (pp. 119-152). Westport, CT: Praeger.

\section{Author's biographical data}

Michael J. Ryan (United States). PhD in Anthropology. Adjunct Professor in the Africana and Latino Studies Department. SUNY Oneonta. He is Editor in Chief of The Immersion Review, a journal for martial comprehensivists, and author of Venezuelan Stick Fighting: The Civilizing Process in Martial Arts (Lanham, MD: Lexington Press, 2017). E-mail: ryanmj@oneonta.edu 